\title{
Effects of Cutting Intensity and Stirring Speed on Syneresis and Curd Losses During Cheese Manufacture
}

\author{
C. D. Everard, ${ }^{\star 1}$ D. J. O’Callaghan, ${ }^{*}$ M. J. Mateo, ${ }^{*}$ C C. P. O’Donnell,, M. Castillo,‡ and F. A. Payneł \\ ${ }^{*}$ Teagasc, Moorepark Food Research Centre, Fermoy, Co. Cork, Ireland \\ †Biosystems Engineering, School Agriculture, Food Science and Veterinary Medicine, University College Dublin, Earlsfort Terrace, \\ Dublin 2, Ireland \\ ‡Department of Biosystems and Agricultural Engineering, University of Kentucky, 128 C.E. Barnhart Building, Lexington $40546-0276$
}

\begin{abstract}
Recombined whole milk was renneted under constant conditions of $\mathrm{pH}$, temperature, and added calcium, and the gel was cut at a constant firmness. The effects of cutting and stirring on syneresis and curd losses to whey were investigated during cheese making using a factorial design with 3 cutting modes designed to provide 3 different cutting intensity levels (i.e., total cutting revolutions), 3 levels of stirring speed, and 3 replications. These cutting intensities and stirring speeds were selected to give a wide range of curd grain sizes and curd shattering, respectively. Both factors affected curd losses, and correct selection of these factors is important in the cheesemaking industry. Decreased cutting intensity and increased stirring speed significantly increased the losses of fines and fat from the curd to the whey. Cutting intensities and stirring speeds in this study did not show significant effects on curd moisture content over the course of syneresis. Levels of total solids, fines, and fat in whey were shown to change significantly during syneresis. It is believed that larger curd particles resulting from low cutting intensities coupled with faster stirring speeds resulted in a higher degree of curd shattering during stirring, which caused significant curd losses.
\end{abstract}

Key words: syneresis, cutting, stirring, whey solid

\section{INTRODUCTION}

Syneresis influences acidity and moisture, mineral, and lactose content of the curd before ripening, which in turn affect texture, color, and flavor (i.e., overall quality) of cheese (Walstra, 2004; Castillo et al., 2006). Losses of fines and fat to whey are highly influenced by syneresis conditions and impact on cheese yield (Castillo et al., 2006). Factors affecting cheese yield have

Received August 21, 2007.

Accepted March 18, 2008.

${ }^{1}$ Corresponding author: colm.everard@teagasc.ie tremendous practical implications and have been reviewed several times (Lucey and Kelly, 1994; Morison, 1997).

Syneresis is promoted by the cutting of milk gel into cubes. The cutting phase during cheesemaking allows bonds to be broken, inducing syneresis. During this cheesemaking phase, shrinkage of the casein micelle network induces whey expulsion (Everard et al., 2007). The curd particles are usually stirred in the increasing volume of expelled whey for a predetermined length of time during which the majority of syneresis takes place.

It is widely accepted that 1-dimensional flow of whey out of curd is governed by Darcy's law (Van Dijk and Walstra, 1986; Lucey, 2002; Castillo et al., 2006). In other words, whey flow rate is directly proportional to the pressure gradient of the liquid in the direction of flow $\Delta P / \Delta x\left(\mathrm{~Pa} \cdot \mathrm{m}^{-1}\right)$ and the curd permeability coefficient $B\left(\mathrm{~m}^{2}\right)$ and inversely proportional to whey viscosity $\eta(\mathrm{Pa} \cdot \mathrm{s})$.

Most factors affecting syneresis exert their effects by means of modifying Darcy's equation terms, $\Delta P / \Delta x, B$, or $\eta$ (e.g., temperature would modify them all). Syneresis rate and extent are widely reported to be affected by indirect factors such as milk pretreatment, milk coagulation processing conditions, and rheological and microstructural gel properties at cutting (Marshall, 1982, Lucey, 2001; Walstra et al., 2001). Apart from cutting several processing parameters (direct syneresis factors) such as time, temperature, agitation, size of curd particles, and volume of liquid surrounding the curd particles all affect the syneresis rate (Lawrence, 1959a,b). Factors affecting syneresis have been reviewed by Walstra et al. (1985). However, the effects of mechanical treatments (e.g., cutting intensity and the accumulated resting time and stirring speed) on syneresis are not widely reported and need further investigation. According to Dejmek and Walstra (2004), cutting disrupts the gel structure, creating cracks in the gel that initiate and influence syneresis. In fact, curd grain sizes, and in turn syneresis, are intrinsic of the extent of cutting. Smaller curd particles provide 
Table 1. Cutting modes ${ }^{1}$ employed in this study which provides differing cutting intensity (CI) levels

\begin{tabular}{|c|c|c|c|c|c|c|c|}
\hline \multirow[b]{3}{*}{$\begin{array}{l}\text { Cutting } \\
\text { modes/CI }\end{array}$} & \multicolumn{3}{|c|}{ Cycle 1} & \multicolumn{3}{|c|}{ Cycles 2 and 3} & \multirow{3}{*}{$\begin{array}{l}\text { Total } \\
\text { revolutions } \\
\text { during } \\
\text { cutting }\end{array}$} \\
\hline & \multicolumn{2}{|c|}{ Cut } & \multirow{2}{*}{$\frac{\text { Rest }}{\begin{array}{c}\text { Duration } \\
(\mathrm{s})\end{array}}$} & \multicolumn{2}{|c|}{ Cut } & \multirow{2}{*}{ 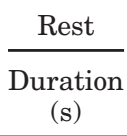 } & \\
\hline & $\begin{array}{l}\text { Duration } \\
\text { (s) }\end{array}$ & $\begin{array}{l}\text { Speed } \\
(\mathrm{rpm})\end{array}$ & & $\begin{array}{l}\text { Duration } \\
\text { (s) }\end{array}$ & $\begin{array}{l}\text { Speed } \\
(\mathrm{rpm})\end{array}$ & & \\
\hline Low & 10 & 5 & 50 & 10 & 10 & 50 & 4.13 \\
\hline Medium & 20 & 5 & 40 & 20 & 10 & 40 & 8.33 \\
\hline High & 30 & 5 & 30 & 30 & 10 & 30 & 12.5 \\
\hline
\end{tabular}

${ }^{1}$ Each cutting mode consisted of 3 cutting/resting cycles of 1 min each.

more surface area for syneresis and also shorten the distance through which whey has to travel in permeating through the curd (Dejmek and Walstra, 2004). Smaller curd particles thus shrink more than larger ones (Dejmek and Walstra, 2004). Other studies have confirmed decreases in the relevant shrinkage with increased curd diameter/thickness for rennet-induced gels (Grundelius et al., 2000; Lodaite et al., 2000). However, these studies were not carried out in cheese vats and were not stirred. Johnston et al. $(1991,1998)$ found that for below-average cutting intensity, large curd particles remained after cutting, and these particles were disintegrated by shattering during the subsequent stirring phase producing small curd particles that release more fat to the whey. The opposite effect was observed by increasing the duration, speed of cutting, or both. The study also reported that cheesemakers observed how a continuous cutting speed results in a curd being pushed in front of the knives, and to break this pattern a nonuniform cutting speed is required.

Whitehead and Harkness (1954) evaluated the effect of stirring speed on curd moisture but, surprisingly, no significant effects were observed. Patel et al. (1972) reported slight increases in syneresis with increased agitation from 35 to $70 \mathrm{rpm}$, in a 5 -L vat containing 2 $\mathrm{L}$ of milk. Lawrence (1959b) reported an increase in whey yield from unstirred to stirred curd in troughs measuring $10 \times 10 \times 10 \mathrm{~cm}$ (1-L volume) and stirring using mechanically driven paddles of dimension $4 \times$ $1.5 \mathrm{~cm}$.

The objectives of this study were to quantify the effects of different gel cutting intensities and their interactive effects with stirring speed on syneresis indices and whey solids in an 11-L cheese vat. These effects are important to the cheesemaker to reduce curd and fat losses during cheesemaking and thus improve process and quality control.

\section{MATERIALS AND METHODS}

\section{Experimental Design}

In this study cheese curd was made from recombined milk in an 11-L vat, following a typical cheese-making recipe (i.e., heating the milk to an optimum temperature for coagulation, adding rennet and stirring briefly, waiting until a coagulum has formed and has set, and then cutting it to form a cheese curd). For the purpose of this study, our trials ended at the point of curd drainage-we did not salt, press, and mature the curd. A randomized factorial experiment with 2 experimental factors (cutting intensity and stirring speed) and 3 replicates was used in this study to evaluate the effects on syneresis indices and curd losses. Three levels of cutting intensity and 3 stirring speeds were investigated using constant coagulation conditions (i.e., constant coagulation temperature and milk $\mathrm{pH}$ as well as constant added rennet and calcium chloride concentrations). Cutting modes were specially designed to provide specific cutting intensities of $4.13,8.33$, and 12.5 revolutions, respectively. Each cutting mode consisted of 3 cutting/ resting cycles of 1-min duration for a total of $3 \mathrm{~min}$ for each mode. Irrespective of the cutting mode, cutting was performed at $5 \mathrm{rpm}$ during the first cycle and 10 rpm during the second and third cycles. The cut/rest duration within the mode was as specified in Table 1 (Johnston et al., 1998; Everard et al., 2007). The 3 levels of stirring speed used were 10,16 , and $22 \mathrm{rpm}$. A total of 27 trials $\left(n a b=3^{3}\right)$ were performed using this design.

\section{Milk Preparation and Gel Formation}

In this study whole milk was recombined in an 11L double-O cheese vat (Type CAL 10L, Pierre Guerin Technologies, Mauze, France) from low-heat skim milk powder (Irish Dairy Board, Dublin, Ireland), distilled water, and cream (Dairygold, Cork, Ireland) to a target protein level of $33 \mathrm{~g} / \mathrm{L}$ at $42 \pm 0.1^{\circ} \mathrm{C}$ while being stirred at $44 \mathrm{rpm}$. Compositional analysis of the recombined milk was determined by Milkoscan (Milko Scan 605, A/ S N. Foss Electric, Hillerød, Denmark) to determine milk fat $\left(\boldsymbol{F a t}_{\mathbf{M}}\right)$, protein, and lactose contents. The composition of the skim milk powder was fat $(0.5 \mathrm{~g} / 100 \mathrm{~g})$, protein $(37 \mathrm{~g} / 100 \mathrm{~g})$, lactose (53 g/100 g), minerals (6 g/ $100 \mathrm{~g})$, and water $(4 \mathrm{~g} / 100 \mathrm{~g})$. One batch of milk powder was used throughout the experiment to minimize the experimental sources of variability. Normal cream com- 


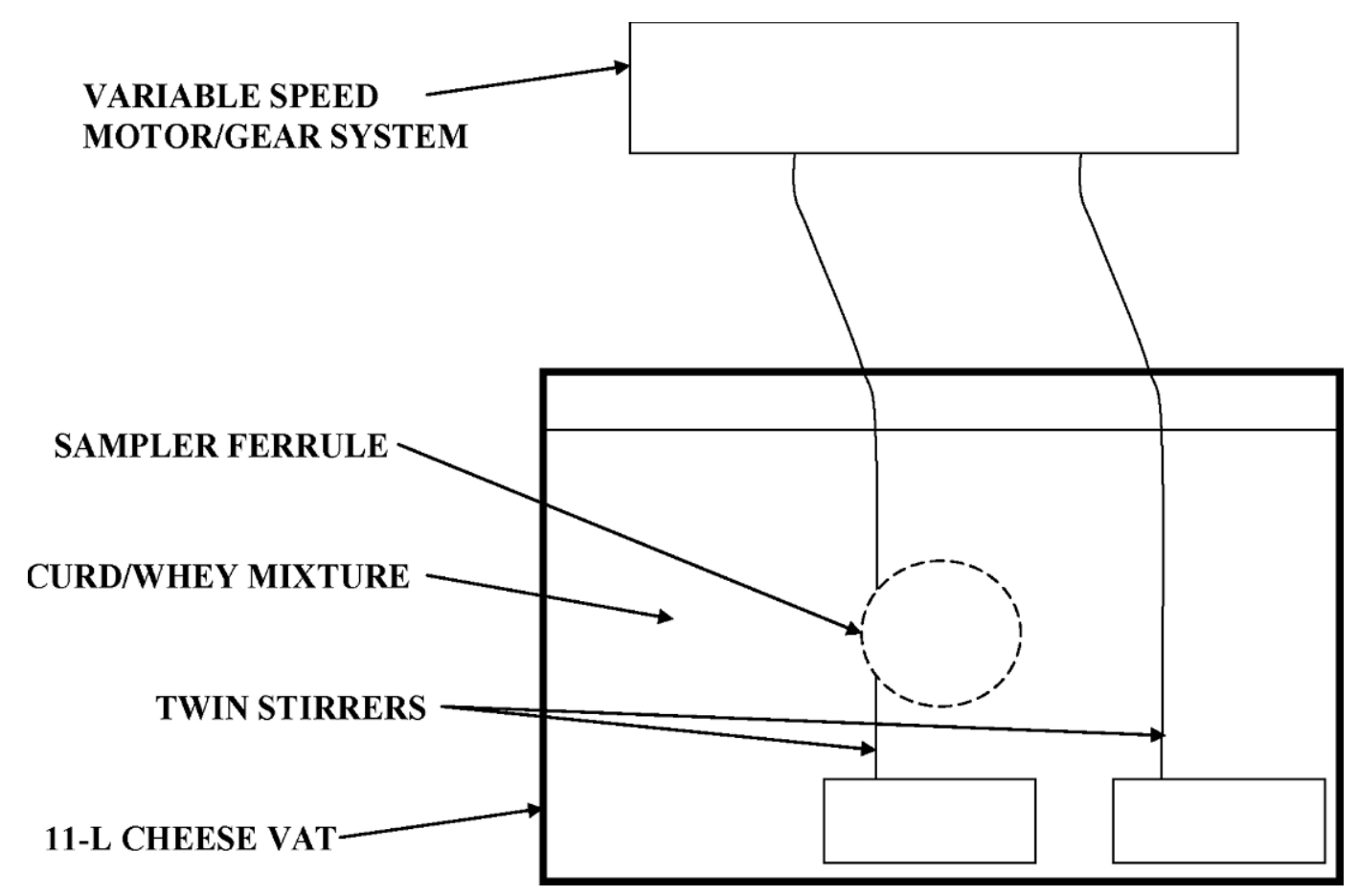

Figure 1. Schematic of the 11-L double-O cheese vat (Pierre Guerin Technologies, Mauze, France) used in this study, also showing the twin counter-rotating stirrers and the position of the ferrule in which the curd and whey sampler is mounted.

position used for milk recombining formulation was fat $(47 \mathrm{~g} / 100 \mathrm{~g})$, protein $(1.6 \mathrm{~g} / 100 \mathrm{~g})$, lactose $(2.3 \mathrm{~g} / 100 \mathrm{~g})$, and water ( $49 \mathrm{~g} / 100 \mathrm{~g})$; however, it was seen that the cream varied from this, which resulted in variations in the milk composition. Calcium chloride was added to the milk $(2.04 \mathrm{mM})$, which was then cooled to $8^{\circ} \mathrm{C}$ and stirred constantly at $10 \mathrm{rpm}$ overnight. The double-O cheese vat had twin overlapping counter-rotating stirrers. The stirring blades $(80 \times 50 \mathrm{~mm})$ were set at an angle of $30^{\circ}$, with a clearance of 8 to $10 \mathrm{~mm}$ from the bottom of the vat, which resulted in a 3-dimensional flow of curd/whey mixture during stirring (Figures 1 and $2 \mathrm{a}$ ). The stirrers were connected to a variable speed motor via a gear system (Figure 2a). Temperature was controlled $\left( \pm 0.1^{\circ} \mathrm{C}\right)$ by a water bath (Grant Y28, Grant Instruments Ltd., Cambridge, UK) via a heating jacket on the vat.

On the day of analysis the milk was heated to $32^{\circ} \mathrm{C}$ and $\mathrm{pH}$ was measured $\left(\boldsymbol{p H}_{32}\right)$ and then adjusted to 6.5 using $\mathrm{HCl}(1 M) 1$ to $2 \mathrm{~h}$ before rennet addition. This was carried out to give setting times similar to fresh milk and to minimize the effects of any $\mathrm{pH}$ variation in added cream. The $p H_{32}$ varied from 6.5 to 6.61 and between 0 and $14 \mathrm{~mL}$ of $\mathrm{HCl}$ was used to adjust the $\mathrm{pH}$. Milk temperature was measured with a precision temperature probe (T-loop Probe Thermometer, Sensor Tech Ltd., Castlebellingham, Co. Louth, Ireland). The milk coagulant used was $100 \%$ recombinant chymosin (CHY-MAX Plus, EC 3.4.23.4, isozyme B, 600 IMCU/ $\mathrm{mL}$; Chr Hansen Ireland Ltd., Cork, Ireland). The rennet was added to the milk ( $0.18 \mathrm{~g}$ of chymosin $/ \mathrm{kg}$ of milk) in the vat while being stirred constantly at 31 rpm. Stirring was stopped after $3 \mathrm{~min}$ and the stirrers were replaced with cutting blades (Figures 1 and $2 \mathrm{~b}$ ). Each cutting blade had 6 vertical knives and 1 horizontal knife that connected the vertical knives near the bottom of the vat (Figure $2 b$ ).

\section{Rheological Determination of Cutting Time}

After rennet addition a 13-mL sample of milk was transferred from the vat into a rheometer cup that was prewarmed to the assay temperature (Bohlin CVO Rheometer, Bohlin, Cirencester, UK), which was used to determine the gel cutting time $\left(\boldsymbol{t}_{\text {cut }}\right)$. The rheometer geometry consisted of a cylindrical bob and cup operating at $32^{\circ} \mathrm{C}$ in oscillation mode at a shear strain of 0.01 at a frequency of $1 \mathrm{~Hz}$. The shear strain used was within the region of linear viscoelastic response $(<0.03)$ reported for rennet milk gels (Mishra et al., 2005). When the elastic modulus $\left(\boldsymbol{G}^{\prime}\right)$ reached $35 \mathrm{~Pa}$, cutting was initiated using the twin set of cutting blades. The moment of initiating gel cutting (i.e., $\boldsymbol{t}_{\text {cut }}$ ) was taken as the reference time $(t=0)$ for all subsequent syneresisrelated measurements. 


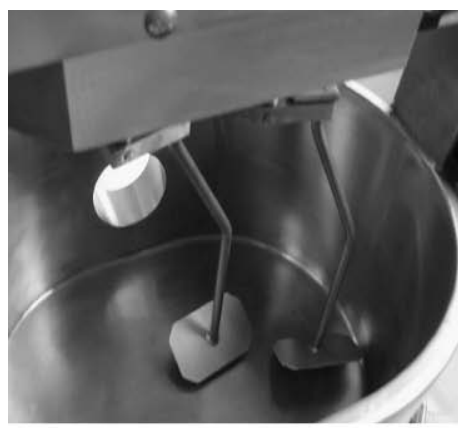

(a)

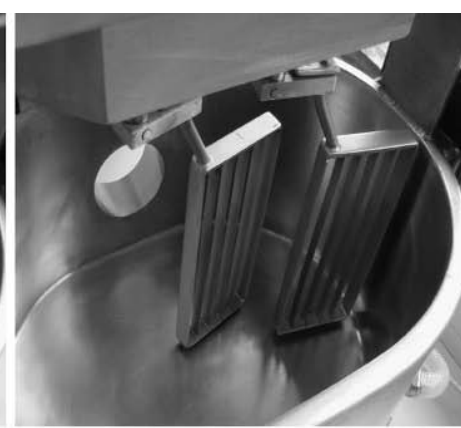

(b)

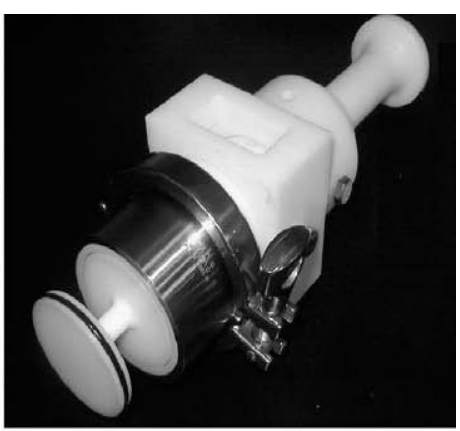

(c)

Figure 2. (a) The double-O cheese vat with twin counter-rotating stirrers, also showing the sampler ferrule situated at approximately mid-height on the vat wall. (b) The vat with counter-rotating cutting blades, each cutting blade had 6 vertical knives and one horizontal knife that connected the vertical knives near the bottom of the vat. The sampler ferrule can also be seen. (c) The specially designed sampler for sampling curd and whey from the vat.

After gel cutting, the cutting blades were replaced by the stirrers and stirring commenced at $t=4$ min.

\section{Measurements of Syneresis Indices and Whey Solids}

Samples of curd/whey mixture were removed from the vat, using a specially designed sampler, manufactured in the University of Kentucky in collaboration with Teagasc and University College Dublin (Figures 1 and 2c). The sampler has a chamber that is filled when a plunger is pushed into the vat interior and withdrawn. The sample is released from the chamber outside the vat when the plunger is withdrawn (Figure $2 c)$. Samples of $\sim 180 \mathrm{~mL}$ were drawn at $5,25,45$, and $65 \mathrm{~min}$, and $\sim 270 \mathrm{~mL}$ samples were drawn at 15, 35, 55 , and $75 \mathrm{~min}$ for analysis. Fines in whey $\left(\right.$ Fines $\left._{\mathrm{W}}\right)$, fines in whey on a milk basis (Fines WM $_{\text {}}$ ), fat in whey $\left(\boldsymbol{F a t}_{\mathrm{W}}\right)$, and fat in whey on a milk basis $\left(\boldsymbol{F a t} \boldsymbol{t}_{\mathrm{WM}}\right)$ were determined at 15, 35, 55, and 75 min only, hence the increased volume of sample taken at these times. Whey was immediately drained from the curd following the procedure proposed by Fagan et al. (2007) and Everard et al. (2007), using a 75- $\mu \mathrm{m}$ numerical aperture stainless steel sieve (AGB, Dublin, Ireland); the sieve characteristics were selected to ensure that whey fat globules were not retained. The 2 phases (curd and whey, respectively) were weighed without delay using a precision balance for whey yield $\left(\boldsymbol{Y}_{\mathbf{W}}\right)$ calculation. The $Y_{\mathrm{W}}$ was calculated as the weight of whey in the sample expressed as a percentage of the weight of the curd and whey sample. Approximately $3 \mathrm{~g}$ of curd and $5 \mathrm{~g}$ of whey were then accurately weighed into preweighed aluminum dishes for determination of curd moisture $\left(\boldsymbol{M}_{\mathbf{C}}\right)$, whey total solids $\left(\boldsymbol{S}_{\mathbf{W}}\right)$, and whey total solids in the curd and whey sample $\left(\boldsymbol{S}_{\mathbf{W M}}\right)$ by drying in triplicate in a convection oven at $102^{\circ} \mathrm{C}$ for $16 \mathrm{~h}$ (Fagan et al., 2007; Everard et al., 2007). The $Y_{\mathrm{W}}, M_{\mathrm{C}}, S_{\mathrm{W}}$, and $S_{\mathrm{WM}}$ were determined at all sample points (i.e., 5 min to 75 min at 10 -min intervals). The final whey yield $\left(\boldsymbol{F} \boldsymbol{Y}_{\mathbf{W}}\right)$ was determined at $\sim 85 \mathrm{~min}$. It was calculated as the total weight of whey expressed as a percentage of the total weight of whey and curd. The $F a t_{\mathrm{W}}$ and $F a t_{\mathrm{WM}}$ were measured using the Rose-Gottlieb method (IDF, 1987). The Fines ${ }_{\mathrm{W}}$ and Fines WM $_{\mathrm{Wm}}$ were determined using a procedure adapted from Johnston et al. (1991), starting with a $45-\mathrm{mL}$ sample that was centrifuged for 15 $\min$ at $1,500 \times g$. The fat layer was removed using a spatula and the supernatant phase was poured off without disturbing the pellet and the fat residue from the side of the tubes was wiped off with a tissue. A volume of $\sim 45 \mathrm{~mL}$ of distilled water was added to the centrifuge tubes, and this sample was centrifuged at $1,500 \times g$ for a further 15 min to remove any remaining fat. The supernatant phase was again poured off without disturbing the pellet. The pellet was washed onto GF/R filter paper in a Bückner funnel attached to a vacuum pump, using $50 \mathrm{~mL}$ of $40^{\circ} \mathrm{C}$ distilled water. The filter paper with fines was dried in an oven at $102^{\circ} \mathrm{C}$ for $1 \mathrm{~h}$ and then allowed to cool to room temperature in a desiccator for 30 min. The Fines $\mathrm{W}$ and Fines ${ }_{\mathrm{WM}}$ were expressed as the weight of fines over the weight of the whey sample and the weight of the curd and whey sample, respectively.

\section{Statistical Analysis}

Analysis of covariance (ANCOVA) was carried out, using the Proc Mixed procedure in SAS 9.1 (SAS Institute Inc., Cary, NC) to determine the factors affecting syneresis indices and whey solids during syneresis. The co-variates $\mathrm{pH}_{32}$ and $\mathrm{Fat}_{\mathrm{M}}$ were included in the model 
Table 2. Analysis of covariance (ANCOVA) and $F$-statistic showing the effects of cutting intensity, stirring speed, and time and their interactive effects on syneresis indices and whey total solids $\left(\mathrm{pH}_{32} \text { and } \mathrm{Fat}_{\mathrm{M}} \text { are covariates }\right)^{1,2}$

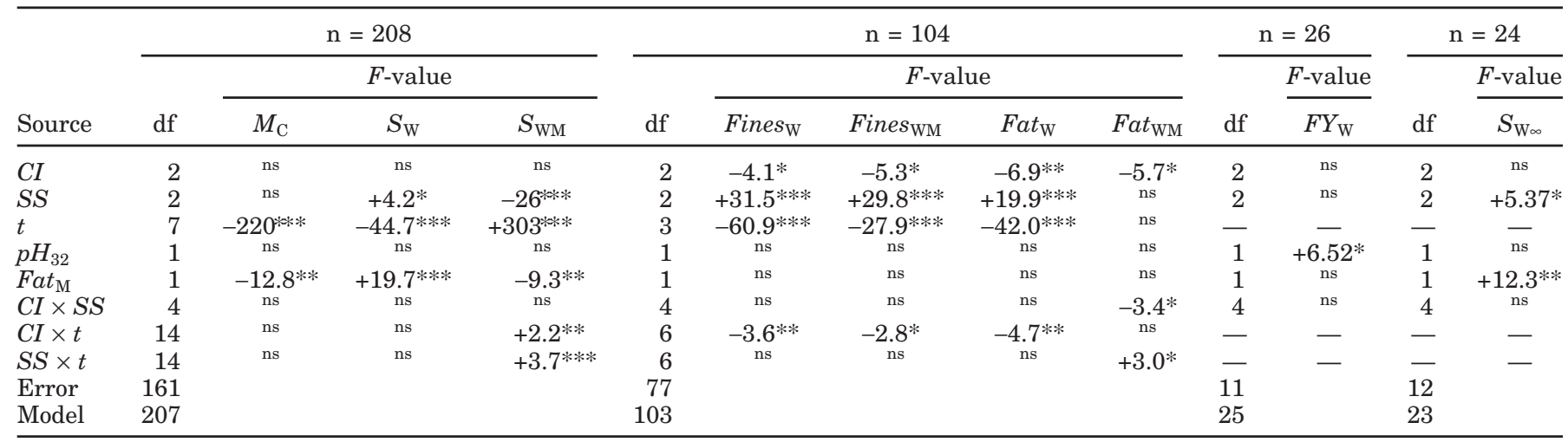

${ }^{1}$ Key for parameters: $M_{\mathrm{C}}$, curd moisture; $S_{\mathrm{W}}$, whey total solids; $S_{\mathrm{WM}}$, whey total solids in the curd and whey sample; Fines ${ }_{\mathrm{W}}$, fines in whey; Fines $_{\mathrm{WM}}$, fines in whey in the curd and whey sample; $F a t_{\mathrm{W}}$, fat in whey; $F a t_{\mathrm{WM}}$, fat in whey in the curd and whey sample; $F Y_{\mathrm{W}}$, final yield of whey; $S_{\mathrm{W}_{\infty}}$, predicted whey total solids at an infinite time, cf. Eq. (3); $t$, time; $p H_{32}, \mathrm{pH}$ value at $32^{\circ} \mathrm{C}$ before acid addition; $F a t_{\mathrm{M}}$, fat content of milk; $C I$, cutting intensity; SS, stirring speed.

${ }^{2}$ ANCOVA: n, number of data points; $F$-value, ANCOVA $F$-statistic.

${ }^{3}$ It was found that 3 trials did not converge to Eq. [1] for $S_{\mathrm{W}}$.

${ }^{* * *} P<0.001 ; * * P<0.01 ; * P<0.05 ;{ }^{\mathrm{ns}}$ not significant. + or - sign indicates positive or negative effect, respectively.

as they varied randomly outside the control of the experiment mostly due to seasonal effects on the cream (Tables 2 and 3 ). The $S_{\mathrm{W}}$ as a function of time during syneresis was fitted to a first order equation Eq. [1] (Castillo et al., 2005; Fagan et al., 2007) using the Proc NLIN procedure in SAS.

$$
S_{W t}=S_{W \infty}+\left(S_{W 5}-S_{W \infty}\right) e^{-\mathrm{SW}^{t}}
$$

where $\boldsymbol{S}_{\mathrm{Wt}}$ predicted whey total solids (g/100 g) at time $t$ (min), $\boldsymbol{S}_{\mathbf{W}_{\infty}}$ the whey total solids at an infinite time, $\boldsymbol{S}_{\text {W5 }}$ the whey total solids (g/100 g) at 5 min after $t_{\text {cut }}$, and $\boldsymbol{k}_{\mathrm{SW}}$ was the kinetic rate constant $\left(\mathrm{min}^{-1}\right)$ for whey total solids changes over the course of syneresis. Procedure NLIN in SAS was used to estimate $S_{\mathrm{W} \infty}, S_{\mathrm{W} 5}$, and $k_{\mathrm{SW}}$.

Multiple linear regressions (MLR) were used to predict curd losses over the course of syneresis, using SigmaStat V 3.1 (Systat Software UK Ltd., London, UK).

\section{RESULTS AND DISCUSSION}

Recombined milk fat content varied from 2.9 to 3.9 $\mathrm{g} / 100 \mathrm{~g}$, protein content varied from 3.30 to $3.38 \mathrm{~g} / 100$ $\mathrm{g}$, and lactose content varied from 4.1 to $4.3 \mathrm{~g} / 100 \mathrm{~g}$. The $t_{\text {cut }}$ varied from 31.5 to $42.5 \mathrm{~min}$. The ANCOVA was conducted to determine the main sources of variation in the dependent variables and $F$-statistic values were reported (Tables 2 and 3). Cutting intensity did not show significant effects on syneresis extent [i.e., $Y_{\mathrm{W}}$, $F Y_{\mathrm{W}}$, and $M_{\mathrm{C}}$ (Tables 2 and 3)] but did cause significant effects on curd losses to the whey [i.e., Fines ${ }_{\mathrm{Wm}}$ and
$F a t_{\mathrm{WM}}$ (Tables 2 and 3, Figure 3)]. Within the cutting intensity range of this study, increased gel cutting intensity resulted in decreased Fines ${ }_{\mathrm{WM}}$ and Fat ${ }_{\mathrm{WM}}$ (Tables 2 and 3). Comparison of the effect of cutting procedures between authors is challenging as the cutting area, cutter tip speed, vat configuration, and plane of cutting all influence the cutting intensity (Johnston et al., 1998). In our study we used a double-O vat with overlapping cutters and the total number of revolutions ranged from 4.2 to 12.5 (Table 1). Johnston et al. (1991, 1998) found similar results working with both vertical axis double-O (Ost, Damrow) and horizontal axis (Tetra Tebel, Ost) cheese vats. They observed that when the curd undergoes a low cutting intensity (lower than $\sim 30$ and $\sim 40$ revolutions for Ost and Tetra Tebel Ost vats, respectively), what they called a shattering effect re-

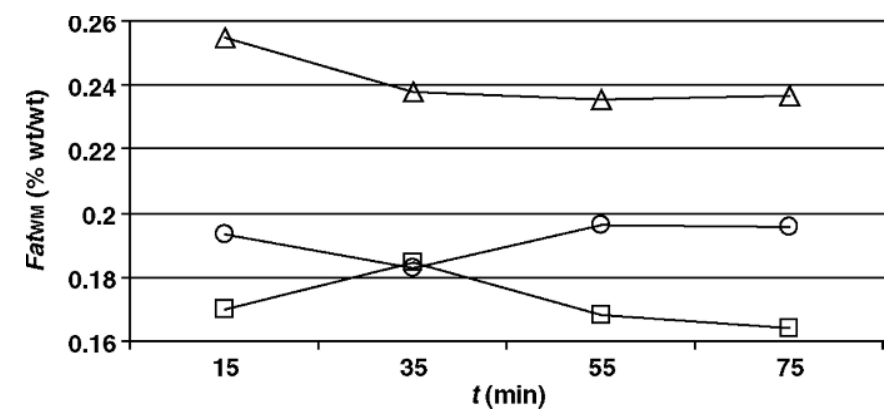

Figure 3. Changes in fat in whey $\left(F_{a} t_{\mathrm{WM}}\right)$ with cutting intensity at the high stirring speed over the course of syneresis. Low cutting intensity $(\triangle)$; medium cutting intensity $(\bigcirc)$; high cutting intensity ( $\square$ ). $t=$ time. These values are averages of triplicates. 
Table 3. Least squares means and analysis of covariance (ANCOVA) of cutting intensities, stirring speeds, and time with respect to syneresis indices and whey solids ( $p H 32$ and $F_{a t} t_{M}$ are covariants) ${ }^{1}$

\begin{tabular}{|c|c|c|c|c|c|c|c|}
\hline \multirow[b]{2}{*}{ Source } & \multicolumn{7}{|c|}{ Syneresis indices and whey solids } \\
\hline & $\begin{array}{c}Y_{\mathrm{W}} \\
(\mathrm{g} / 100 \mathrm{~g})\end{array}$ & $\begin{array}{c}M_{\mathrm{C}} \\
(\mathrm{g} / 100 \mathrm{~g})\end{array}$ & $\begin{array}{c}S_{\mathrm{WM}} \\
(\mathrm{g} / 100 \mathrm{~g})\end{array}$ & $\begin{array}{l}\text { Fines }_{\mathrm{WM}} \\
(\mathrm{mg} / \mathrm{kg})\end{array}$ & $\begin{array}{c}F_{a t_{\mathrm{WM}}} \\
(\mathrm{g} / 100 \mathrm{~g})\end{array}$ & $\begin{array}{c}F Y_{\mathrm{W}} \\
(\mathrm{g} / 100 \mathrm{~g})\end{array}$ & $\begin{array}{c}S_{\mathrm{W}_{\infty}} \\
(\mathrm{g} / 100 \mathrm{~g})\end{array}$ \\
\hline \multicolumn{8}{|c|}{$C I^{2}$ (total revolutions) } \\
\hline Low & $49.9^{\mathrm{a}}$ & $81.3^{\mathrm{a}}$ & $3.12^{\mathrm{a}}$ & $89^{\mathrm{a}}$ & $0.205^{\mathrm{a}}$ & $72.5^{\mathrm{a}}$ & $6.22^{\mathrm{a}}$ \\
\hline Medium & $49.3^{\mathrm{a}}$ & $81.6^{\mathrm{a}}$ & $3.07^{\mathrm{a}}$ & $66^{\mathrm{b}}$ & $0.175^{\mathrm{b}}$ & $72.2^{\mathrm{a}}$ & $6.20^{\mathrm{a}}$ \\
\hline High & $49.4^{\mathrm{a}}$ & $81.5^{\mathrm{a}}$ & $3.06^{\mathrm{a}}$ & $57^{\mathrm{b}}$ & $0.184^{\mathrm{b}}$ & $73.3^{\mathrm{a}}$ & $6.18^{\mathrm{a}}$ \\
\hline \multicolumn{8}{|l|}{$S S$ (rpm) } \\
\hline 10 & - & $81.6^{\mathrm{a}}$ & $3.40^{\mathrm{a}}$ & $35^{\mathrm{a}}$ & $0.188^{\mathrm{ab}}$ & $72.5^{\mathrm{a}}$ & $6.15^{\mathrm{a}}$ \\
\hline 16 & - & $81.3^{\mathrm{a}}$ & $2.97^{\mathrm{b}}$ & $68^{\mathrm{b}}$ & $0.179^{\mathrm{ac}}$ & $72.3^{\mathrm{a}}$ & $6.20^{\mathrm{ab}}$ \\
\hline 22 & - & $81.5^{\mathrm{a}}$ & $2.89^{\mathrm{b}}$ & $109^{c}$ & $0.197^{\mathrm{b}}$ & $73.1^{\mathrm{a}}$ & $6.25^{\mathrm{b}}$ \\
\hline \multicolumn{8}{|l|}{$t(\min )$} \\
\hline 5 & $16.4^{\mathrm{a}}$ & $86.9^{\mathrm{a}}$ & $1.07^{\mathrm{a}}$ & - & - & - & - \\
\hline 15 & $48.9^{b}$ & $83.0^{\mathrm{b}}$ & $3.07^{\mathrm{b}}$ & $91^{\mathrm{a}}$ & $0.184^{\mathrm{ab}}$ & - & - \\
\hline 25 & $49.3^{\mathrm{b}}$ & $81.7^{\mathrm{c}}$ & $3.06^{\mathrm{b}}$ & - & - & - & - \\
\hline 35 & $55.9^{c}$ & $80.9^{\mathrm{d}}$ & $3.47^{\mathrm{c}}$ & $66^{\mathrm{b}}$ & $0.195^{\mathrm{a}}$ & - & - \\
\hline 45 & $52.3^{\mathrm{d}}$ & $80.6^{\mathrm{d}}$ & $3.26^{\mathrm{d}}$ & - & - & - & - \\
\hline 55 & $56.9^{c}$ & $79.9^{\mathrm{e}}$ & $3.53^{\mathrm{c}}$ & $60^{\mathrm{b}}$ & $0.183^{\mathrm{b}}$ & - & - \\
\hline 65 & $56.0^{\mathrm{c}}$ & $79.9^{\mathrm{e}}$ & $3.47^{\mathrm{c}}$ & - & - & - & - \\
\hline 75 & $60.4^{\mathrm{e}}$ & $79.1^{\mathrm{f}}$ & $3.73^{\mathrm{e}}$ & $65^{\mathrm{b}}$ & $0.190^{a b}$ & - & - \\
\hline
\end{tabular}

${ }^{a-f}$ Least squares means followed by same letters are not significantly different.

${ }^{1}$ Key for parameters: $Y_{\mathrm{W}}$, yield of whey; $M_{\mathrm{C}}$, curd moisture; $S_{\mathrm{WM}}$, whey total solids in the curd and whey sample; Fines ${ }_{\mathrm{WM}}$, fines in whey in the curd and whey sample; Fat ${ }_{\mathrm{WM}}$, fat in whey in the curd and whey sample; $F Y_{\mathrm{W}}$, final yield of whey; $S_{\mathrm{W}_{\infty}}$, predicted whey total solids at an infinite time, cf. Eq. [3]; $p H_{32}, \mathrm{pH}$ value at $32^{\circ} \mathrm{C}$ before acid addition; $F a t_{\mathrm{M}}$, fat content of milk; $t$, time; $C I$, cutting intensity; $S S$, stirring speed.

${ }^{2}$ cf. Table 1.

sulted during the subsequent stirring of the curd. This shattering effect is caused by the larger curd particles from low intensity cutting being further reduced in size by the action of the stirrers, effectively breaking down the curd particles resulting in increased curd losses. It would appear that the maximum cutting revolutions used in our studies, being much less than the maximum in those cited studies was not great enough to show the damaging effect of too intensive cutting; on the other hand our range of cutting revolutions was well within the range needed to show the adverse effects of belowoptimum cutting. Furthermore, the smaller scale (11 L) of our vat compared with commercial vats (typically $20,000 \mathrm{~L}$ ) resulted in much lower relative velocities between cutting knives and curd in our study. This is consistent with increased shattering with decreased cutting intensity and increased stirring speeds leading to increased losses of fines and fat to the whey. Shattering gives a more jagged curd surface than that caused by cutting, resulting in increased surface area on curd particles through which fat losses occur (Johnston et al., 1991). Olson (1977) and Barbano and Sherbon (1984) have reported on disruptive effects of shattering. These studies have both reported on excessive stirring in a cheese vat resulting in increased fat losses to the whey and reduced curd yield. Increased resting periods allow for the curd particles to become firmer (Olson, 1977; Mayes and Sutherland, 1989). In our study, whereas the less intensive cutting cycles were accompanied by slightly longer rest periods, the durations of these rest periods were relatively short for the purpose of healing and did not lessen the shattering effect.

There was no decrease in $F a t_{\mathrm{WM}}$ between medium and high cutting intensities (Table 3 ). This may indicate that an optimum cutting intensity was reached for fat loss due to the balance between increased surface area due to cutting and decreased curd shattering. Increased syneresis with cutting intensity found in studies without stirring (Lodaite et al., 2000) was less evident in this study possibly due to a dominant shattering effect of the relatively large curd particles during stirring.

It is hypothesized that greater stirring speeds increased the shattering effect on the curd particles due to increased collisions between the stirrers and curd and between the curd particles themselves, thus significantly increasing Fines ${ }_{\mathrm{WM}}$ and $F a t_{\mathrm{WM}}$ (Tables 2 and 3 , and Figure 4). The decrease in $S_{\mathrm{WM}}$ with increased stirring speed may be due to weak curd grains breaking up upon sampling at the 5 min sampling point; when this sampling point is omitted from data analysis $S_{\mathrm{WM}}$ significantly $(P<0.001)$ increases with stirring speed, as would be expected; this can be seen in the lower section of Table 3. Greater stirring speeds and $F a t_{\mathrm{M}}$ levels significantly increased $S_{\mathrm{W}_{\infty}}$. Johnston et al. (1998) found that increased stirring speed of below average- 


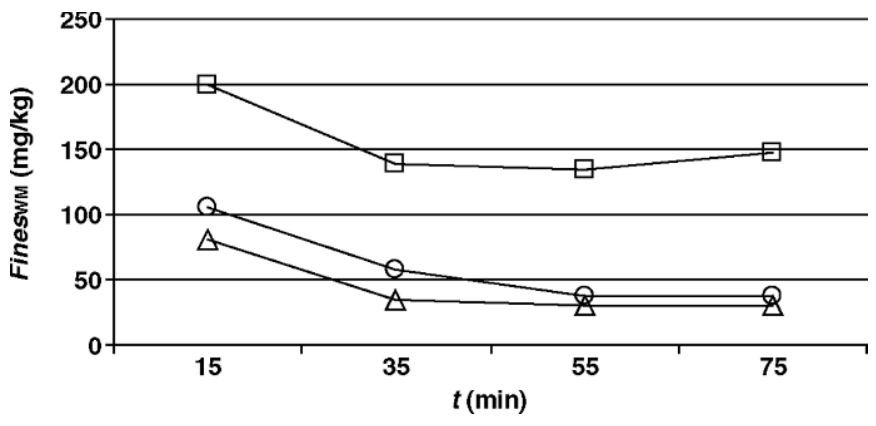

Figure 4. Changes in fines in whey $\left(\right.$ Fines $\left._{\mathrm{WM}}\right)$ with stirring speed at the low cutting intensity over the course of syneresis. Low stirring speed $(\triangle)$; medium stirring speed $(\bigcirc)$; high stirring speed $(\square) . t=$ time. These values are averages of triplicates.

cut gels caused a reduction in curd grain sizes and increased fat losses to the whey.

Stirring curd particles in the whey medium prevents a sedimentation layer of curd particles at the bottom of the vat and compaction of these particles which could obstruct the expulsion of whey from the curd (Everard et al., 2007). Increased stirring speed causes increased dynamic stresses resulting in greater syneresis rates according to Darcy's law. These increased stresses are caused by (i) velocity gradients according to Bernoulli's law and (ii) by short pressure bursts caused by the curd particles colliding with stirrers and with themselves. These phenomena are confirmed by the findings of Lawrence (1959b) and Birkkjaer et al. (1961) who found that removing whey during syneresis speeds up syneresis; this procedure would increase the collisions of curd particles in the system. It has also been reported that external stresses may cause cracks in curd particle surfaces (Akkerman, 1992), increasing the surface area for syneresis. In this study $M_{\mathrm{C}}$ did not change with stirring speed. It is believed that the stirring speeds in this study resulted in curd grains shattering upon collision, and therefore the collision effects on syneresis as governed by Bernoulli's law are different than those reported at lower stirring speeds. We conclude that the cutting intensities and stirring speeds used in this study affected losses of fines and fat to the whey. This study found significant interaction between cutting intensity and stirring speed for $F_{a t} t_{\mathrm{WM}}$ (Table 2). Larger curd particles resulting from less intense cutting are more prone to shattering at a particular stirring speed.

The $S_{\mathrm{W}}$ decreased with time throughout syneresis (Table 2). The $S_{\mathrm{WM}}$ (i.e., the total loss of solids on a milk basis) increased with time, as would be expected. This decrease occurred mostly over the first $15 \mathrm{~min}$ and more slowly, but nevertheless significantly, after that (Table 3 ). The decrease in $S_{\mathrm{W}}$ with time implies that the dilution effect is dominant (i.e., the rate of expulsion of whey slightly exceeded the rate of loss of solids). The Fines $_{\mathrm{W}}$ and Fines ${ }_{\mathrm{WM}}$ both decreased with time; the decrease occurring during the first $\sim 20$ to 30 min of syneresis (Tables 2 and 3, and Figure 4). The decrease in Fines $_{\text {WM }}$ may indicate that some fine particles which are released during cutting have adhered to larger particles during stirring and remain with the curd upon draining. Certainly, after the early rapid phase of syneresis we found no increase in loss of fines to whey. Fat losses to whey on a milk basis, $F a t_{\mathrm{WM}}$, showed no change with time, whereas the dilution effect was evident (Tables 2 and 3).

The covariant $p H_{32}$ had significant effects on $F Y_{\mathrm{W}}$ (Table 2). Adjustment of $\mathrm{pH}$ was carried out approximately 1 to $2 \mathrm{~h}$ before rennet addition; however, the $\mathrm{pH}$ before adjustment still affected syneresis. This may be due to the $\mathrm{pH}$ adjustment not having enough time to fully equilibrate. The $p H_{32}$ has an influence on $t_{\text {cut }}$ $\left(\mathrm{R}^{2}=0.58, P<0.001\right)$. Everard et al. (2007) reported increased syneresis at lower milk $\mathrm{pH}$ levels, within the $\mathrm{pH}$ range 6.0 to 6.5. The $F_{a t}$ had significant effects on $Y_{\mathrm{W}}$ at the low stirring speed $(P<0.05$, not shown), $M_{\mathrm{C}}, S_{\mathrm{W}}, S_{\mathrm{WM}}$, and $S_{\mathrm{WM} \infty}$ (Table 2). The effect on $M_{\mathrm{C}}$ is consistent with the fact that higher fat content of milk has been widely reported to decrease syneresis rate (Walstra et al., 1985). The lack of a clear effect of $F a t_{\mathrm{M}}$ on $F Y_{\mathrm{W}}$ reflects the small variation in milk fat level.

Predictive equations for $S_{\mathrm{WM}}$ and Fines ${ }_{\mathrm{WM}}$ in terms of the experimental parameters were developed using $M L R$, showing standard errors of estimate (SEy)

Table 4. Predictive equations for $S_{\mathrm{WM}}$, Fines $_{\mathrm{WM}}$, and Fat $_{\mathrm{WM}}$ developed using multilinear regression $(\mathrm{MLR})^{1}$

\begin{tabular}{|c|c|c|c|c|c|c|c|}
\hline $\begin{array}{l}\text { Dependent } \\
\text { variable }\end{array}$ & $\begin{array}{l}\text { Significant factors } \\
\qquad(P<0.05)^{2}\end{array}$ & $\mathrm{df}$ & Significance $^{3}$ & $\mathrm{R}$ & Adjusted $\mathrm{R}^{2}$ & SEy & Range \\
\hline$S_{\mathrm{WM}}$ & $t, S S, F a t_{\mathrm{M}}$ & 208 & $* * *$ & 0.73 & 0.52 & $0.61(\mathrm{~g} / 100 \mathrm{~g})$ & $4.12(\mathrm{~g} / 100 \mathrm{~g})$ \\
\hline Fines $_{\mathrm{WM}}$ & $S S, C I, t, t_{\mathrm{cut}}, F_{\mathrm{M}}, p \mathrm{H}_{32}$ & 104 & $* * *$ & 0.85 & 0.70 & $22(\mathrm{mg} / \mathrm{kg})$ & $209(\mathrm{mg} / \mathrm{kg})$ \\
\hline
\end{tabular}

${ }^{1}$ Key for parameters: $S_{\mathrm{WM}}$, whey total solids in the curd and whey sample; Fines ${ }_{\mathrm{WM}}$, fines in whey in the curd and whey sample; $t$, time; $F_{\text {a }} t_{\mathrm{M}}$, fat content of milk; $C I$, cutting intensity; $S S$, stirring speed; $p H_{32}, \mathrm{pH}$ value at $32^{\circ} \mathrm{C}$ before acid addition; $t_{\text {cut }}$, cutting time; $\mathrm{SEy}$, standard error of estimate.

${ }^{2}$ Significant factors are listed in order of decreasing significance based on ratio between each coefficient and its standard error.

${ }^{3}$ Model significance: $* * * P<0.001$. 
amounting to 10 to $13 \%$ of the range of these parameters. The significant factors for $S_{\mathrm{WM}}$ were $t, S S$, and $F_{\text {at }}$, with $R=0.73$, and a standard error of estimate of $0.61 \mathrm{~g} / 100 \mathrm{~g}$ (Table 4). The significant factors for Fines $_{\mathrm{WM}}$ were $S S, C I, t, t_{\text {cut }}, F_{\mathrm{M}} t_{\mathrm{M}}$, and $p H_{32}$ and with $\mathrm{R}=0.85$ and $\mathrm{SEy}=22 \mathrm{mg} / \mathrm{kg}$ of whey (Table 4).

Results show the effects of low intensity cutting and its interactive effect with curd stirring speed, which can be used to help the cheesemaker control curd losses during cheesemaking that influence final cheese yield. These findings highlight the effects of undercutting cheese curd and show that increasing stirring speed of undercut curd leads to significant losses of fines and fat to whey.

\section{CONCLUSIONS}

The study found that lower cutting intensities and higher stirring speeds significantly increased the losses of fines and fat from curd to whey during the syneresis phase of cheesemaking. The authors conclude that if the cheese gel is not adequately cut, a shattering effect will occur during the subsequent stirring phase of syneresis. The shattering effect results in curd grains being further reduced in size by the action of stirrers. This shattering effect, which is promoted by less intense cutting and higher stirring speeds, led to increased loss of fines and fat to whey.

\section{ACKNOWLEDGMENTS}

Funding for this research was provided under the National Development Plan, through the Food Institutional Research Measure (FIRM), administered by the Irish Department of Agriculture, Fisheries and Food (DAF).

\section{REFERENCES}

Akkerman, J. K. 1992. Drainage of curd. PhD thesis. Wageningen Agricultural University, Wageningen, the Netherlands.

Barbano, D. M., and J. W. Sherbon. 1984. Cheddar cheese yields in New York. J. Dairy Sci. 67:1873-1883.

Birkkjaer, H. E., B. J. Sörensen, J. Jorgensen, and B. Sigersted. 1961. The effect of cheesemaking techniques on cheese quality. Beretn. Statens Forsögsmejeri, 128.

Castillo, M. Z., J. A. Lucey, T. Wang, and F. A. Payne. 2006. Effect of temperature and inoculum concentration on gel microstructure, permeability and syneresis kinetics. Cottage cheese type gels. Int. Dairy J. 16:153-163.

Castillo, M., F. A. Payne, M. B. Lopez, E. Ferrandini, and J. Laencina. 2005. Preliminary evaluation of an optical method for modelling the dilution of fat globules in whey during syneresis of cheese curd. Appl. Eng. Agric. 21:265-268.

Dejmek, P., and P. Walstra. 2004. The syneresis of rennet-coagulated curd. Pages 71-101 in Cheese: Chemistry, Physics and Microbiol- ogy. Vol. 1: General Aspects. P. F. Fox, ed. 3rd ed. Chapman \& Hall, London, UK.

Everard, C. D., D. J. O’Callaghan, C. C. Fagan, C. P. O’Donnell, M. Castillo, and F. A. Payne. 2007. Computer vision and colour measurement techniques for inline monitoring of cheese curd syneresis. J. Dairy Sci. 90:3162-3170.

Fagan, C. C., M. Castillo, F. A. Payne, C. P. O'Donnell, M. Leedy, and D. J. O'Callaghan. 2007. A novel on-line sensor technology for continuous monitoring of milk coagulation and whey separation in cheese making. J. Agric. Food Chem. 55:8836-8844.

Grundelius, A. U., K. Lodaite, K. Östergren, M. Paulsson, and P. Dejmek. 2000. Syneresis of submerged single curd particles and curd rheology. Int. Dairy J. 10:489-496.

International Dairy Federation. 1987. Milk. Determination of fat content-Röse Gottlieb gravimetric method. IDF (FIL-IDF standard 1C), Brussels, Belgium.

Johnston, K. A., F. P. Dunlop, and M. F. Lawson. 1991. Effects of speed and duration of cutting in mechanised Cheddar cheesemaking on curd particle size and yield. J. Dairy Res. 58:345-354.

Johnston, K. A., M. S. Luckman, H. G. Lilley, and B. M. Smale. 1998. Effect of Various cutting and stirring conditions on curd particle size and losses of fat to the whey during Cheddar cheese manufacture in Ost vats. Int. Dairy J. 8:281-288.

Lawrence, A. J. 1959a. Syneresis of rennet curd. Part 1-Effect of time and temperature. Aust. J. Dairy Technol. 14:166-169.

Lawrence, A. J. 1959b. Syneresis of rennet curd. Part 2-Effect of stirring and of the volume of whet. Aust. J. Dairy Technol. 14:169-172

Lodaite, K., K. Ostergren, M. Paulsson, and P. Dejmek. 2000. Onedimensional syneresis of rennet-induced gels. Int. Dairy J. 10:829-834.

Lucey, J., and J. Kelly. 1994. Cheese yield. J. Soc. Dairy Technol. 47:1-14.

Lucey, J. A. 2001. The relation between rheological parameters and whey separation in milk gels. Food Hydrocolloids 15:603-608.

Lucey, J. A. 2002. ADSA Foundation Scholar Award formation and physical properties of milk protein gels. J. Dairy Sci. 85:281-294.

Marshall, R. 1982. An improved method for measurement of the syneresis of curd formed by rennet action on milk. J. Dairy Res. 49:329-336

Mayes, J. J., and B. J. Sutherland. 1989. More notes on coagulum firmness and yield in Cheddar cheese manufacture. Aust. J. Dairy Technol. 34:47-48.

Mishra, R., S. Govindasamy-Lucey, and J. A. Lucey. 2005. Rheological properties of rennet-induced gels during the coagulation and cutting process: Impact of processing conditions. J. Texture Stud. 36:190-212.

Morison, K. R. 1997. Cheese manufacture as a separation and reaction process. J. Food Eng. 32:179-198.

Olson, N. F. 1977. Factors affecting cheese yields. Dairy Industries Int. 42:14-15, 19.

Patel, M. C., D. B. Lund, and N. F. Olson. 1972. Factors affecting syneresis of renneted milk gels. J. Dairy Sci. 55:913-918.

Van Dijk, H. J. M., and P. Walstra. 1986. Syneresis of curd. 2. Onedimensional syneresis of rennet curd in constant conditions. Neth. Milk Dairy J. 40:3-30.

Walstra, P. 2004. The syneresis of curd. Pages 141-191 in Cheese: Chemistry, Physics and Microbiology. Vol. 1: General Aspects. P. F. Fox, ed. 2nd ed. Chapman \& Hall, London, UK.

Walstra, P., T. J. Geurts, A. Noomen, A. Jellema, and M. A. J. S. van Boekel. 2001. Ciencia de la leche y tecnologia de los productos lacteos. Acribia, S.A., Zaragoza, Spain.

Walstra, P., H. J. M. van Dijk, and T. J. Geurts. 1985. The syneresis of curd. 1. General considerations and literature review. Neth. Milk Dairy J. 39:209-246.

Whitehead, H. R., and W. L. Harkness. 1954. The influence of variations in cheese-making procedure on the expulsion of moisture from Cheddar cheese curd. Aust. J. Dairy Technol. 9:103-107. 